\title{
Masonry infill panels - analytical modeling and seismic behavior
}

\author{
Diana Samoilă \\ Technical University of Cluj-Napoca, Romania
}

\begin{abstract}
The analytical modeling of the in fills implies the determination of their geometrical and mechanical characteristics. The paper presents three one- bay, one- story frames, for which the diagonal strut width and the strength to different failure types are determined. The effects of the masonry infill panels upon the seismic behavior of the frames structures are rendered by the capacity curves obtained from the push-over analysis carried out on a series of concrete frames with different number of stories.
\end{abstract}

Keywords: - capacity curves, diagonal strut width, masonry infills, strength

\section{INTRODUCTION}

The concrete frame structures provided with masonry panels are widely spread in many countries with relatively high seismicity. Either for old structures, build before the development of the seismic codes, or for present time buildings, this concrete-masonry designing solution is preferred due to its advantages: flexible space-arrangement and a regular, compact and symmetrical shape in the horizontal plan.

The masonry panels are usually neglected in the design practice, due to the difficulties in identifying the mechanical characteristics and the types of failure of the infills. The overall influence upon the structure is also considered difficult to predict, so the masonry infills are generally viewed as non-structural elements. However, this approach is very simplistic and approximate, as it has been observed that, under the action of the horizontal forces resulting from the seismic action, the masonry infill can decisively influence the response of the structure.

The European Standard Eurocode 8 [1] refers to the infill panels as elements that do not contribute to the lateral resistance. On the other hand, the definition of a "non-structural" element excludes infill panels, since they are able to bear horizontal loads. After all, even if the role of the masonry infills in the seismic behavior of the structure is recognized, there is a caution in considering them as "structural", especially due to the lack of reliable numerical models.

The purpose of this paper is to present a comparison between several methods of modeling the infill and to establish some guidelines on determining the diagonal strut width and the strength on the panel. Based on these recommendations, a nonlinear analysis of several frames is carried out, in order to highlight the increase of the structures' stiffness and strength due to the presence of the infills.

In the first part, the paper presents the main research studies about the diagonal strut width and the formulae contained in three national codes for determining the strength of the infilled frames. A comparative analysis between three one-bay, one-story frames with masonry infills is also performed. The purpose is to apply several equations for the strut width and to draw conclusions on their similarities and differences. The in plane failure modes of the infill proposed by the Romanian seismic code [2] are compared to those indicated in FEMA [3] and New Zeeland [4] code. The section's aim is to determine a reliable and practical model for introducing the infill panels in the design practice.

The second part of the paper deals with the seismic behavior of concrete frames with masonry infills. A series of pushover analyses have been carried out on bare frames, on frames separated from the panel through joints and on frames that interact with the masonry. The influence of the masonry upon the global behavior comes from the capacity curves. The increase stiffness and overall resistance of the structures are higher for the frames in contact with the masonry panels than for the structures with the masonry isolated from the surrounding frame.

\section{RELATED RESEARCH STUDIES}

\subsection{The width of the diagonal strut}

A large number of researchers have studied the behavior of infilled frames, starting with Polyakov (1960) [5], and Holmes (1961) [6], which were the first in replacing the infill wall by an equivalent pin-jointed diagonal strut. Holmes, as a result of a large number of numerical simulations and parametric analyses, proposed the width of the strut $w$ as a third of diagonal length $d_{z}$.

Stafford Smith (1966) [7] proposed a theoretical relation for the width of the diagonal strut based on the relative stiffness of infill and frame and introduced the parameter $\lambda_{h}$ : 


$$
\lambda_{h}=\sqrt[4]{\frac{E_{z} \cdot t \cdot \sin 2 \theta}{4 \cdot E_{b} \cdot I_{s} \cdot H}}
$$

where $E_{z}$ is the modulus of elasticity of the masonry, $E_{b}$ is the modulus of elasticity of the concrete, $t$ is the thickness of the panel, $I_{s}$ is the moment of inertia of the column, $H$ is the high of the infill and $\theta$ is the slope angel of the panel's diagonal.

Smith and Carter (1969) [8] suggested that the width of the strut is calculated as:

$$
w=0.58\left(\frac{1}{H}\right)^{-0.445}\left(\lambda_{h} H^{\prime}\right)^{0.335 d_{z}\left(\frac{1}{H}\right)^{0.064}}
$$

where $H^{\prime}$ is the column height.

Using the stiffness parameter $\lambda_{h}$, Mainstone (1974) [9] obtained the following expression (adopted thereafter in the FEMA documents):

$$
w=0.175 d_{z}\left(\lambda_{h} H^{\prime}\right)^{-0.4}
$$

Kadir (1974) [10] reached the conclusion that the dimension of the strut is influenced not only by the adjacent columns, but also by the top beam and, besides the $\lambda_{h}$ factor, proposed the introduction of $\lambda_{g}$ parameter:

$$
\lambda_{g}=\sqrt[4]{\frac{E_{z} \cdot t \cdot \sin 2 \theta}{4 \cdot E_{b} \cdot I_{g} \cdot H}}
$$

The width of the equivalent strut, as a function of the above parameters, is given by:

$$
w=\frac{\pi}{2}\left(\frac{1}{4 \lambda_{h}^{2}}+\frac{1}{4 \lambda_{g}^{2}}\right)
$$

Liaw and Kwan [11] in 1984, on the basis of experimental results of steel frames with masonry infills, suggested the equation:

$$
w=\frac{0.95 H \cos \theta}{\sqrt{\lambda_{h} H^{\prime}}}
$$

Decanini and Fantin (1986) [12] have shown that the effective strut width decreases as the loading is increased, providing several expressions for calculating the strut width:

- $\quad$ uncracked masonry (I)

$$
\begin{array}{rlrlrl}
w & =\left(\frac{0.748}{\lambda_{h}}+0.085\right) d_{z} & \text { if } & & \lambda_{h} \leq 7.85 \\
w & =\left(\frac{0.393}{\lambda_{h}}+0.130\right) d_{z} & \text { if } & & \lambda_{h}>7.85 \\
& \text { cracked masonry (II) } & & \\
w & =\left(\frac{0.707}{\lambda_{h}}+0.010\right) d_{z} & \text { if } & & \lambda_{h} \leq 7.85 \\
w & =\left(\frac{0.470}{\lambda_{h}}+0.040\right) d_{z} & \text { if } & & \lambda_{h}>7.85
\end{array}
$$

Dawe and Seah (1989) [13] suggested a formula based on the $\lambda_{h}$ and $\lambda_{g}$ parameters:

$$
w=\frac{2 \pi}{3}\left(\frac{\cos \theta}{\lambda_{h}}+\frac{\sin \theta}{\lambda_{g}}\right)
$$

Hendry (1990) [14] recommended that the width of the compressed strut should depend on the length of contact along the column and the beam, $\alpha_{h}$ and $\alpha_{L}$ respectively:

$$
w=\frac{1}{2} \sqrt{\alpha_{h}^{2}+\alpha_{L}^{2}}
$$

Paulay and Priestley (1992) [15], following the footsteps of Holmes, suggested that the width of the equivalent strut $w$ is a fourth of $d_{z}$.

According to Bertoldi (1993) [16] research study, based on non-linear finite element method analyses and experimental tests, the value of $w$ is determined by the equation:

$$
\frac{w}{d_{z}}=\frac{k_{1}}{\lambda_{h} \cdot H^{\prime}}+k_{2}
$$

The values of the parameters $k_{1}$ and $k_{2}$ are presented in Table 1 . 
Table 1. $k_{1}$ and $k_{2}$ parameters

\begin{tabular}{|c|c|c|c|}
\cline { 2 - 4 } \multicolumn{1}{c|}{} & $\lambda_{\mathrm{h}} \mathrm{H}^{\prime}<3.14$ & $\begin{array}{c}3.14<\lambda_{\mathrm{h}} \mathrm{H}^{\prime} \\
<7.85\end{array}$ & $\lambda_{\mathrm{h}} \mathrm{H}^{\prime}>7.85$ \\
\hline $\mathrm{k}_{1}$ & 1.3 & 0.707 & 0.47 \\
\hline $\mathrm{k}_{2}$ & -0.178 & 0.01 & 0.04 \\
\hline
\end{tabular}
frame:

Later, Durrani and Luo (1994) [17], provided a formulation which introduces the geometry of the

$$
\begin{array}{r}
w=\gamma \sqrt{L^{\prime 2}+H^{\prime 2}} \sin 2 \theta \\
\gamma=0.32 \sqrt{\sin 2 \theta}\left[\frac{H^{\prime 4} E_{z} t}{m E_{b} I_{s} H}\right]^{-0.1} \\
m=6\left[1+\frac{6 E_{b} I_{g} H^{\prime}}{\pi E_{b} I_{s} L^{\prime}}\right]
\end{array}
$$

$I_{g}$ is the moment of inertia of the beam and $L^{\prime}$ 'is the opening of the frame.

Cavaleri and Papia (2003) [18] introduced the influence of the masonry dilatation on the strut width, according to the following expression:

$$
w=\frac{d_{z} \cdot c}{z} \frac{1}{\left(\lambda^{*}\right)^{\beta}}
$$

where:

$$
\lambda^{*}=\frac{E_{z}}{E_{b}} \frac{t \cdot H^{\prime}}{A_{s}}\left(\frac{H^{\prime 2}}{L^{\prime 2}}+\frac{1}{4} \frac{A_{s}}{A_{g}} \frac{L^{\prime}}{H^{\prime}}\right)
$$

The parameters $c$ and $\beta$ depend on the Poisson coefficient $\gamma$ :

$$
\begin{gathered}
c=0.249-0.0116 \gamma+0.567 \gamma^{2} \\
\beta=0.146+0.0073 \gamma+0.126 \gamma^{2} \\
z=1+0.25\left(\frac{L}{H}-1\right)
\end{gathered}
$$

According to the Romanian seismic code [19], the diagonal strut width should be considered as $d_{z} / 10$.

\subsection{The strength of the infill}

Under the action of earthquake loads the concrete frames with masonry infills may show various failure modes, depending on: the infill dimensions, the mechanical characteristics of masonry and mortar, the infill stress degree, the direction of the lateral force.

Several national codes describe the behavior of this type of structure to seismic action and indicate equations for determining the capacity of the infills to each failure mode. The following equations are those recommended in the Romanian seismic code (CR6-2006), in the FEMA (Federal Emergency Management Agency, USA) documents and in the code from New Zeeland (NZSEE). The formulas refer only to the in plane failure modes.

a. CR6-2006

The Romanian seismic code stipulates that the strength of the infill is the lowest values of the following failure modes:

- $\quad$ sliding shear failure

$$
F_{R d 1}(z u)=\frac{1}{\cos \theta} f_{v d 0} L \cdot t \cdot(1+\alpha)
$$

where $f_{v d 0}$ is the design strength when the compression effort in zero.

$$
\alpha=0.07\left(4 \frac{H}{L}-1\right)
$$

compression corner crushing 


$$
F_{R d 2}(z u)=0,8 \cdot f_{d} \cdot \cos ^{2} \theta \cdot \sqrt[4]{\frac{E_{b}}{E_{z}} I_{s t} \cdot H \cdot t^{3}}
$$

where $f_{d}$ is the design compression strength and $I_{s t}$ is the average value of the moments of inertia of the adjacent columns.

- $\quad$ diagonal tension failure

$$
F_{R d 3}(z u)=\frac{f_{v d 0} \cdot L \cdot t}{0,6 \cos \theta}
$$

b. FEMA 306 contains several potential failure modes and formulas for calculating the strength of the infill: sliding shear failure

$$
V_{l}=\left(\tau_{0}+\sigma_{y} \cdot \operatorname{tg} \phi\right) \cdot L \cdot t=\mu \cdot N
$$

where $\tau_{0}$ is the cohesive capacity of the mortar beds, $\sigma_{y}$ is the vertical stress in the infill, $\phi$ is the angel of sliding friction, $L$ is the length of the infill, $\mu$ is the coefficient of sliding friction along the bed joints and $N$ is the vertical load on the panel.

It is suggested that for small deformations $V_{l}$ is approximately equal to zero. For large deformations due to the vertical load imposed to the infill due to the shortening of the columns, $V_{l}$ is:

$$
V_{l}=\mu \cdot L \cdot t \cdot E_{z} \cdot \theta_{d}^{2}
$$

where $\theta_{d}$ is the interstory drift angle, defined as the ratio of the interstory drift over the height of the column. compression failure

$$
V_{c}=w \cdot t \cdot f_{m 90}^{\prime} \cdot \cos \theta
$$

where $f_{m 90}^{\prime}$ is the expected strength of masonry in the horizontal direction, which may be set at $50 \%$ of the expected stacked $\operatorname{prism} f_{d} ; w$ is the strut width determined with Mainstone formula (3). diagonal tension failure

$$
V_{t}=\frac{2 \sqrt{2} \cdot t \cdot \sigma_{t}}{\left(\frac{L}{H}+\frac{H}{L}\right)}
$$

The cracking strength $\sigma_{t}$ may be taken $20 \sqrt{f_{m e}^{\prime}}\left(f_{m e}^{\prime}=f_{d}\right)$. general shear failure

The initial and final contributions of shear carried by the infill panel are defined as:

$$
\begin{aligned}
& V_{m i}=A_{m} \cdot 2 \cdot \sqrt{f_{m e}^{\prime}} \\
& V_{m f}=0.3 \cdot V_{m i}
\end{aligned}
$$

where $A_{m}$ is the net horizontal shear area of the infill. The above values give upper and lower bounds to the cyclic-loading resistance of the infill.

\section{c. NZSEE}

The code from New Zeeland provides the same in plane failure modes as FEMA 306. For the sliding shear failure and for compression failure the equations are those presented above (26), (28). Different formulations are given for:

Diagonal tension failure

$$
V_{t}=\frac{2 \sqrt{2} \cdot t \cdot L \cdot \sigma_{t}}{\frac{L}{H}+\frac{H}{L}}
$$

where $\sigma_{t}=1.7 \sqrt{f_{m e}^{\prime}}$

$$
\begin{gathered}
V_{m i}=A_{m} \cdot 0.17 \cdot \sqrt{f_{m e}^{\prime}} \\
V_{m f}=0.3 \cdot V_{m i}
\end{gathered}
$$


III. THE MECHANICAL CHARACTERISTICS OF THE INFILL

The case study refers to three different concrete frames with masonry infills with a single bay and a single story. Applying the above expressions - for the strut width and for the strength - the study proposes a comparison of the results and indicates the most suitable model to be used in practical design.

The properties of the materials are indicated in Table 2.

Table 2. The properties of the materials

\begin{tabular}{l|c|c|c|c|c|c|c|c|} 
Materials & $\begin{array}{c}\text { Modulus of } \\
\text { elasticity } \\
{\left[\mathrm{kN} / \mathrm{m}^{2}\right]}\end{array}$ & $\begin{array}{c}\text { Poisson } \\
\text { coefficient }\end{array}$ & $\begin{array}{c}\text { Mean } \\
\text { compressive } \\
\text { strenght } \\
{\left[\mathrm{kN} / \mathrm{m}^{2}\right]}\end{array}$ & $\begin{array}{c}\text { Design } \\
\text { compressive } \\
\text { strenght } \\
{\left[\mathrm{kN} / \mathrm{m}^{2}\right]}\end{array}$ & $\begin{array}{c}\text { Yield } \\
\text { strenght } \\
{\left[\mathrm{kN} / \mathrm{m}^{2}\right]}\end{array}$ & $\begin{array}{c}\text { Design } \\
\text { tensile } \\
\text { strenght } \\
{\left[\mathrm{kN} / \mathrm{m}^{2}\right]}\end{array}$ & $\begin{array}{c}\text { Strain - } \\
\text { maximum } \\
\text { force }\end{array}$ & $\begin{array}{c}\text { Ultimate } \\
\text { strain }\end{array}$ \\
\hline Concrete-C20/25 & $\mathrm{E}_{\mathrm{b}}=30 \mathrm{x} 10^{6}$ & 0.2 & $\mathrm{f}_{\mathrm{cm}}=28000$ & $\mathrm{f}_{\mathrm{cd}}=13300$ & & & $\varepsilon_{\mathrm{cl}}=0.002$ & $\varepsilon_{\mathrm{cul}}=0.0035$ \\
\hline Steel-PC52 (S 345) & $\mathrm{E}_{\mathrm{a}}=200 \times 10^{6}$ & & & & $\mathrm{f}_{\mathrm{yk}}=345000$ & $\mathrm{f}_{\mathrm{yd}}=300000$ & & \\
\hline Masonry & $\mathrm{E}_{z}=4.5 \times 10^{6}$ & 0.19 & & $\mathrm{f}_{\mathrm{d}}=1990$ & & & & \\
\hline
\end{tabular}

The cross section dimensions of the beam are $b_{g} x h_{g}=0.25 x 0.5 \mathrm{~m}$ and of the columns are $b_{s} x h_{s}=0.5 \times 0.5 \mathrm{~m}$. The infill thickness is $0.25 \mathrm{~m}$ and $f_{v d 0}=102 \mathrm{kN} / \mathrm{m}^{2}$.
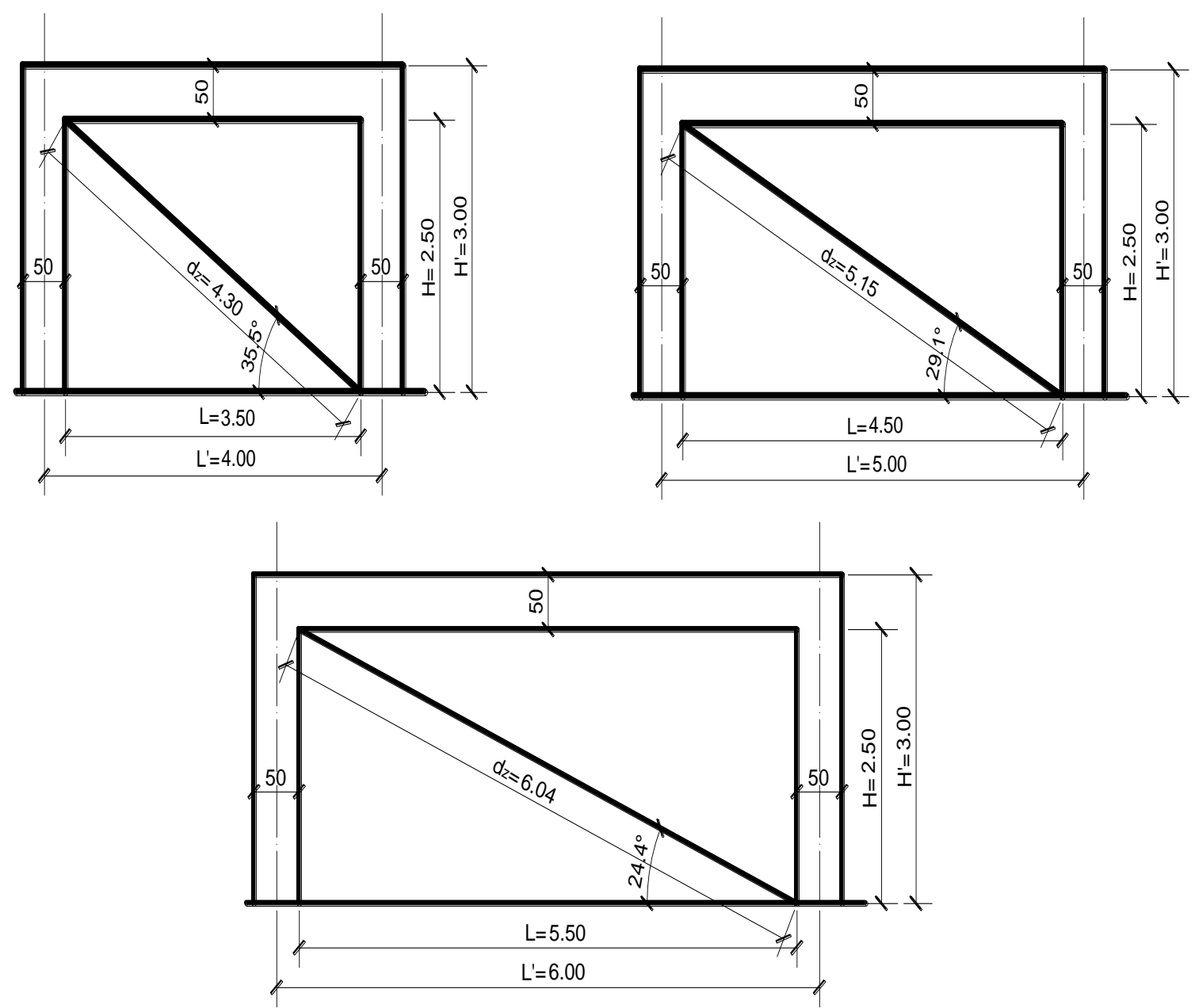

Figure 1. Masonry infilled reinforced concrete frames 


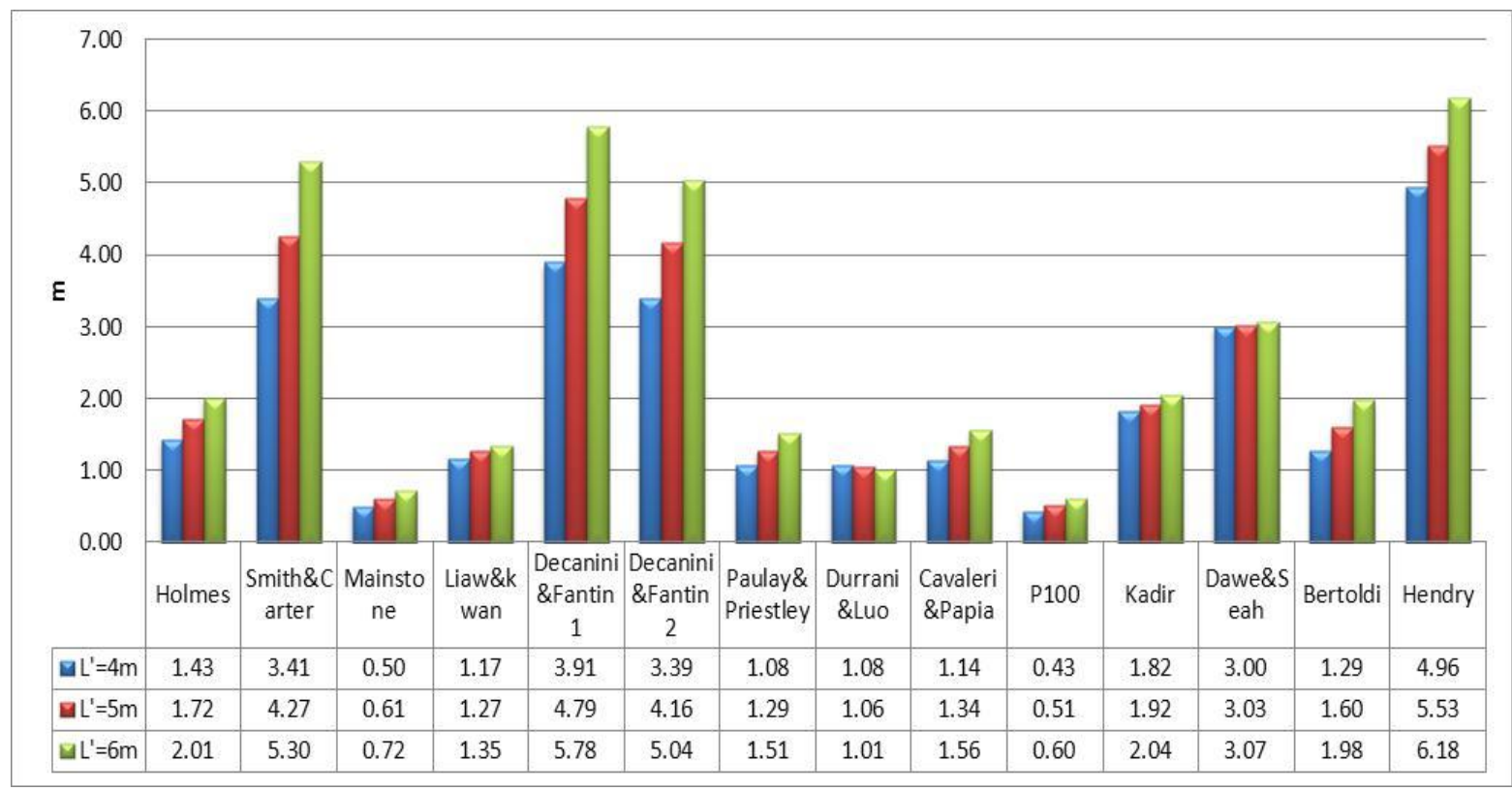

Figure 2. Equivalent strut width.

Placing the resulting values on the same diagram (Fig. 2), one can draw the following conclusions:

1. Smith and Carter, Decanini and Fantin and Hendry equations generate extremely large values for the diagonal strut width.

2. Mainstone relation is very close to that proposed by the Romanian code, both of them being at the inferior limit.

3. The other expressions (Holmes, Liaw and Kwan, Paulay and Priestley, Durrani and Luo, Cavaleri and Papia, Kadir, Bertoldi) are comparable.

4. The strut width increases direct proportional with the infill length for almost all the equations. The exception is Durrani and Luo formulation, for which the diagonal strut width is smaller for higher lengths.

5. Paulay and Priestley relation is recommended to be used in design analysis because it gives an average value and due of its simplicity.

The strength of each frame presented above is determined according the equations recommended in CR62006, FEMA 306 and NZSEE (Fig 3).

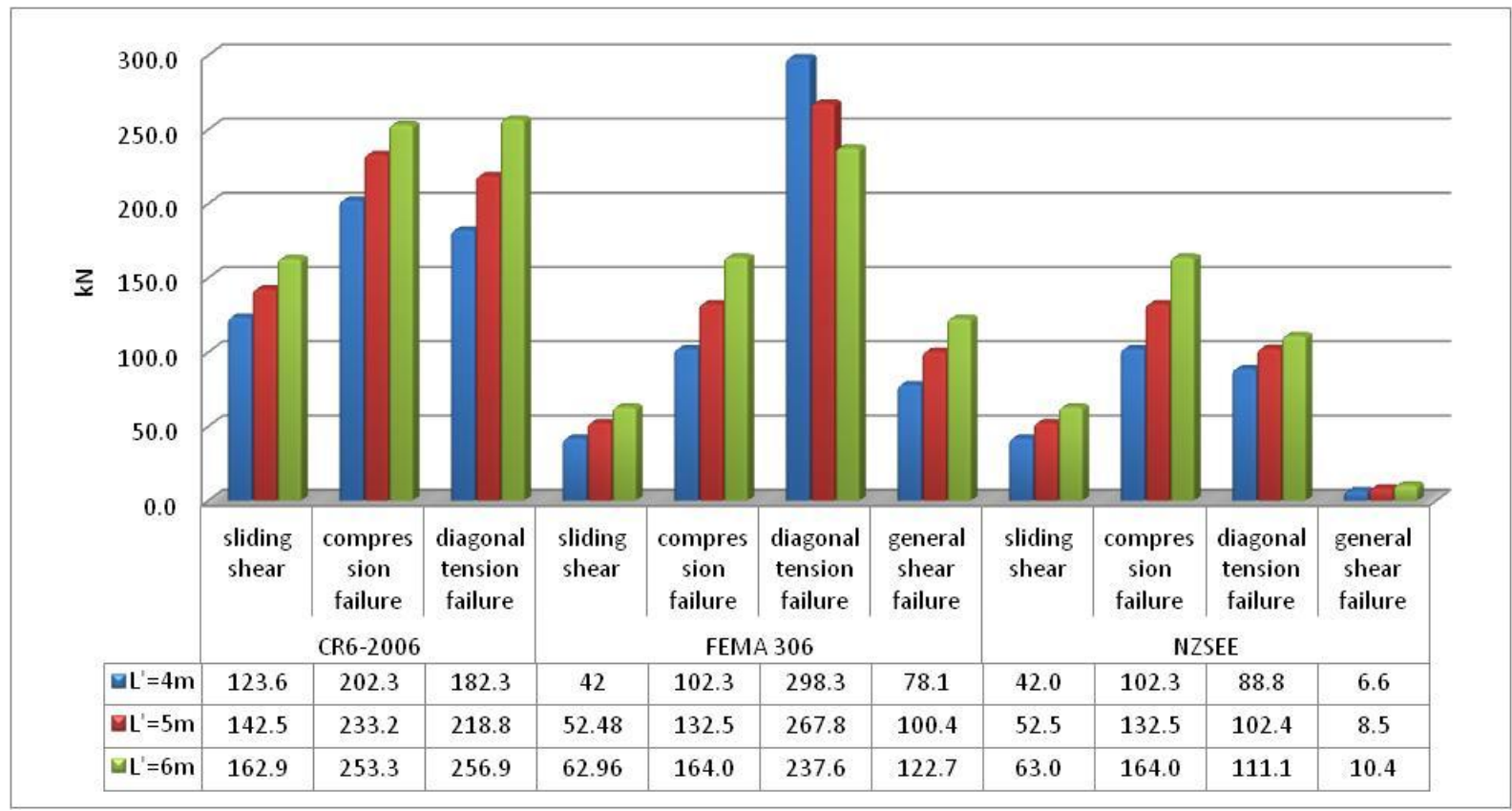

Figure 3. The strength of the infill 
From the above diagram it is obvious that:

1. The capacity of the infill is higher for the frames with higher openings, except the strength to diagonal tension failure according to FEMA 306.

2. The Romanian seismic code envisages relatively high values of the infill failure capacity compared to the other codes.

3. The average value for the strength is $131 \mathrm{kN}$, very close to the value $135 \mathrm{kN}$, recommended in other studies [20].

As a conclusion of the paragraph, the model suggested to be used in the design practice of the concrete frames with masonry infills (with the frame opening between $4 m$ and $6 m$ ) consider the panel as a compressed diagonal strut, with the width calculated using the Paulay and Priestley formula and with a structural capacity of $135 \mathrm{kN}$.

\section{SEISMIC BEHAVIOR}

In order to quantify the influence of the masonry panels upon the structures' behavior to seismic action, a numerical is carried out on a number of 12 plane frames, of different heights $(G F+3 F, G F+4 F, G F+5 F$, $G F+6 F)$ in three different cases of modeling closings and partitions: bare frames, with no masonry, with walls made of light materials (Model I); frames with walls that are separated through joints from the concrete frame (Model II); frames that co-operate with the infill walls in absorbing the seismic lateral forces (Model III). The plane view is given in Fig. 4.

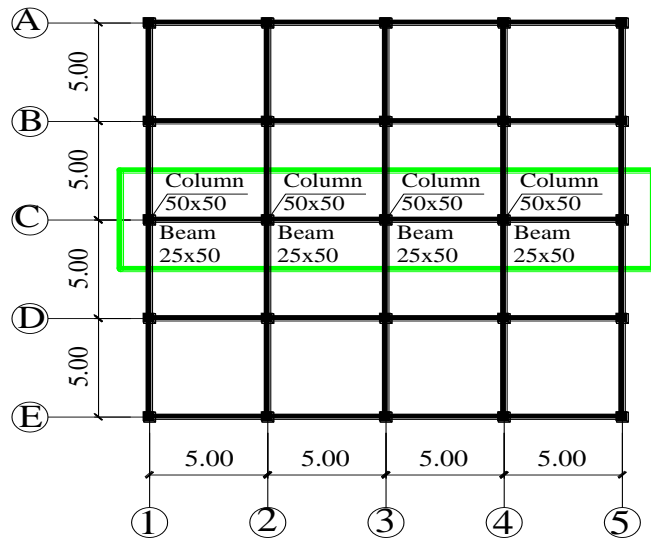

Figure 4. Plane view

The beam and column sections are $0.5 \times 0.25 \mathrm{~m}$ and $0.5 \times 0.5 \mathrm{~m}$, respectively, for all cases. The storey height is $3 m$, and the slab thickness is $0.13 m$.

The masonry walls thickness is $0.25 \mathrm{~m}$. In case the infills are separated from the frame, the masonry is introduced in analysis only as an additional vertical load, having no contribution in the absorbing of the lateral loads. In the situation of assuming the co-operation between frame and infill, the masonry is replaced by a compressed diagonal strut. The width of the diagonal strut is calculated using the Paulay and Priestley equation.

The reinforcement bars in the columns are continuous along their entire length. The columns of the four stories structures have $8 \varphi 16+4 \varphi 12$ longitudinal reinforcement, and the columns of the other frames have $12 \varphi 20$ reinforcement bars. The reinforcement bars in beams are the same, in number and diameter, both in the fields and the bearings, being reduced in the top stories. The frames with masonry infills (Model II and III) have the beams reinforcement increased with aprox 50\% towards the bare frames (Model I).

For the structures that co-operate with the masonry panels (Model III), the stresses resulted from linear elastic analyses are smaller than those obtained for the frames isolated from the masonry (Model II). Nevertheless, Model III frames have been designed similarly to Model II, because the concrete structure should resist to the seismic loads after the infills collapse.

The properties of the materials are given in Table 2 and the stress-strain curves, introduced in the pushover analysis, are presented in Fig. 5. The force-displacement relation in Fig. 5c. describes the behavior of the masonry infill on the diagonal direction, and not the behavior of the masonry to the compression effort. Based on the conclusion of the paragraph III and on the recommendations of Pereira, Baros, Cesar [20], the maximum force in the diagonal strut was considered to be $135 \mathrm{kN}$, associated to a displacement of $0.0012 \mathrm{~m}$.

The structures are assumed to be located in Bucharest, a seismic zone with $a_{g}=0.24 \mathrm{~g}$, according to the Romanian seismic code, P100-1/2006 [19].

After designing the reinforced concrete frames with and without masonry panels, nonlinear pushover analyses were carried out. Intending to model the frames with distributed nonlinearity, the NEFCAD software 
was used. This application uses an event-to-event load increment strategy coupled with an equilibrium error correcting constant arc-length algorithm to solve the geometric and material nonlinearities associated with the ultimate load capacity of a structure.

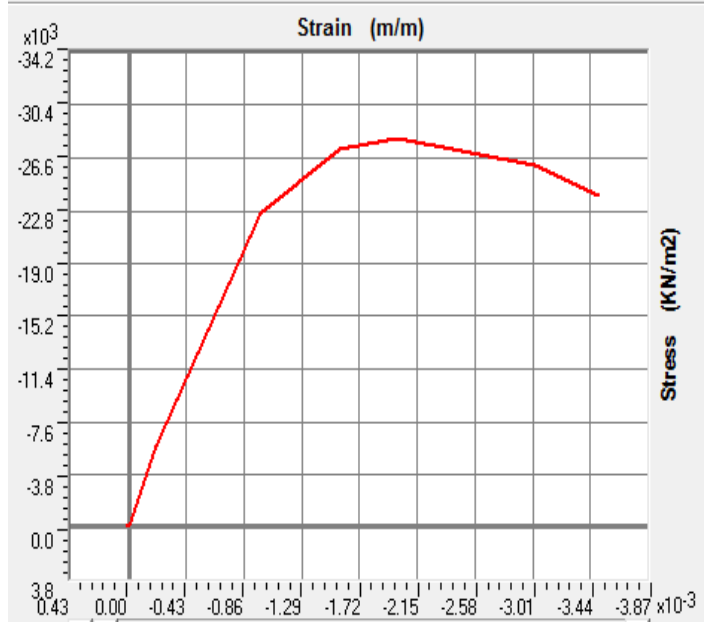

a.

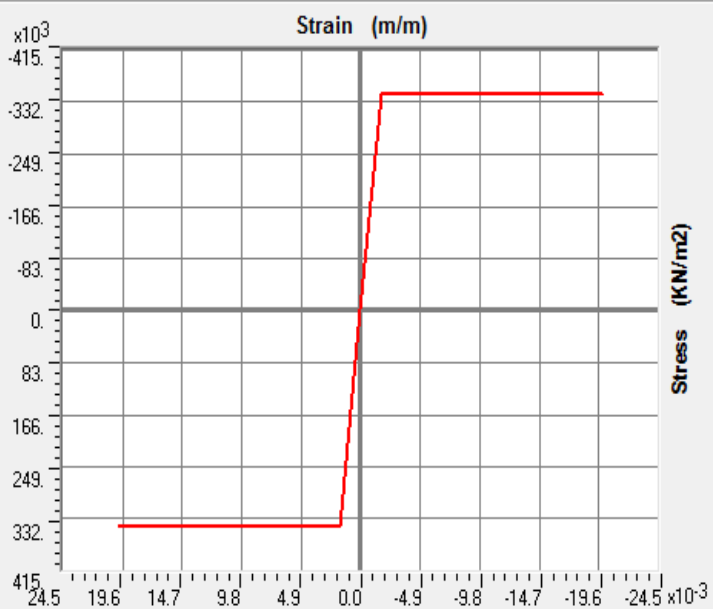

b.

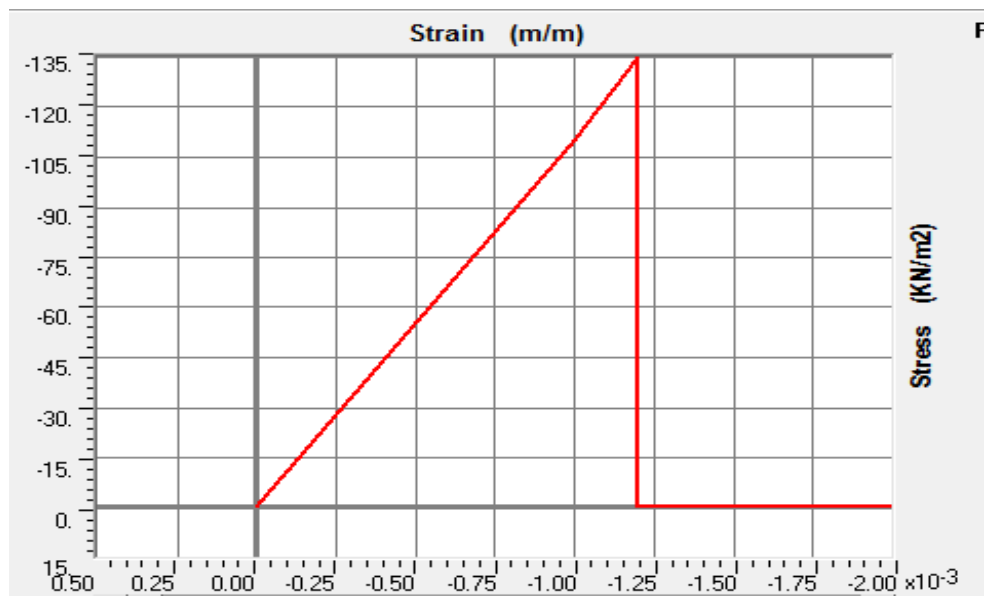

c.

Figure 5. The stress-strain curves: a. concrete; b. steel; c. masonry

The capacity curves obtained from the pushover analyses represent the variation of the base shear force related to the displacement of the top of the structure, being presented in the following figures (Fig. 6, 7, 8, 9). The force-displacement curves of each model are presented on the same diagram, for a specific storey number $(G F+3 F, G F+4 F, G F+5 F, G F+6 F)$. The curves are displayed until the collapse of the structure occurs, namely until the descending slope is reached.

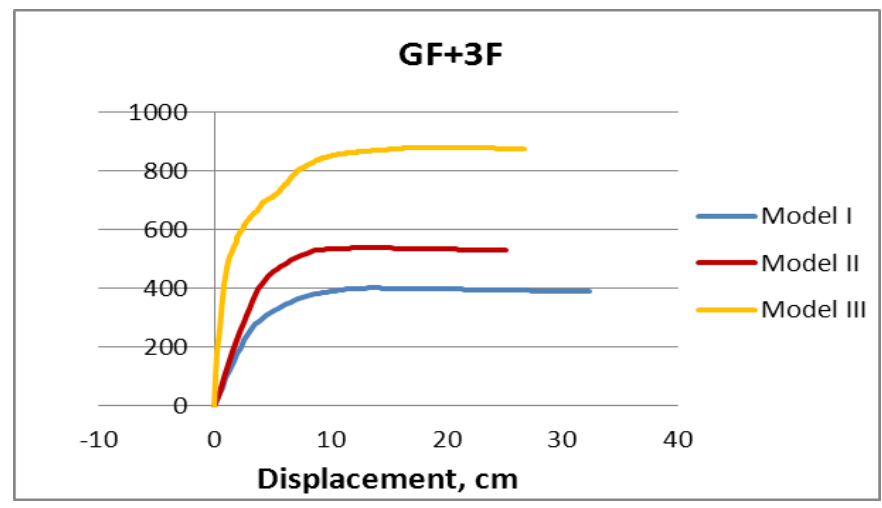

Figure 6. Capacity curves for structures with GF+3F 


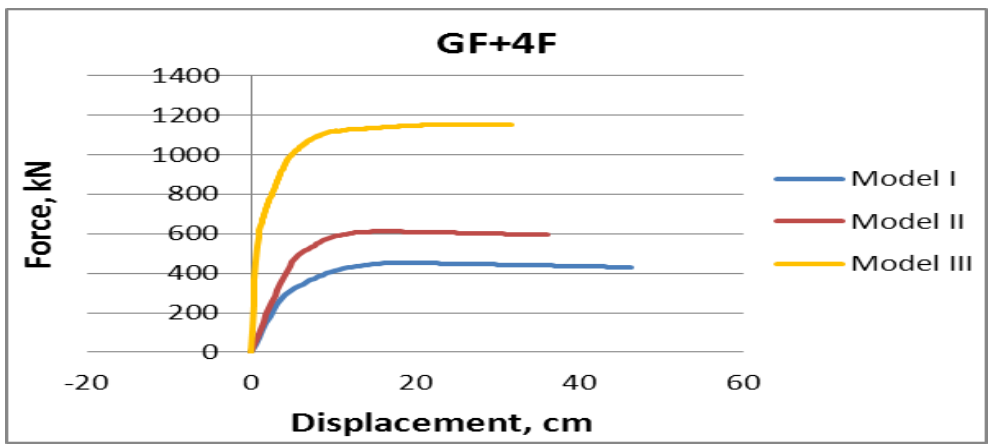

Figure 7. Capacity curves for structures with GF+4F

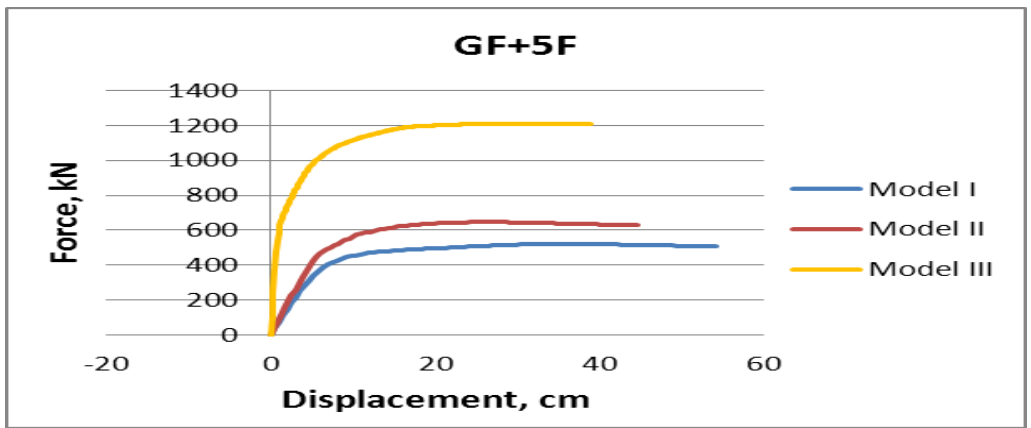

Figure 8. Capacity curves for structures with $\mathrm{GF}+5 \mathrm{~F}$

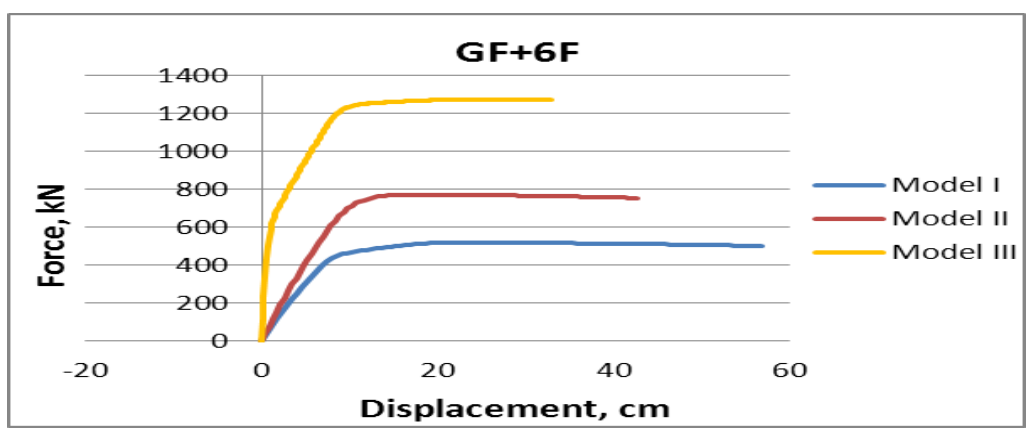

Figure 9. Capacity curves for structures with $\mathrm{GF}+6 \mathrm{~F}$

It can be observed that the structures having masonry infills (Model II and Model III) show a higher load-carrying capacity as compared to the frames without masonry (Model I). The increase is of 35\% for Model II and of $138 \%$ for Model III, the percentages being an average of the studied cases. These results reveal the positive contribution of masonry infills to the overall resistance capacity of the structure, especially in the case in which the masonry is not separated from the concrete frame.

As for the stiffness of the structures, it is obvious that the curves of the infilled frames that co-operate with masonry have an inclination of the linear elastic segment substantially higher towards the bare frame curves. For a specific value of the base shear force, the top displacement of the frames in Model III is much smaller than for the frames in Model I and Model II, meaning that the infilled frames in Model III are stiffer. The percentage of $721 \%$ specific to Model III is relevant for the positive effect of the masonry upon the reinforced concrete frames.

\section{CONCLUSION}

Beginning with the 50's, the concrete frames with masonry infills have been a subject of great interest for the scientific community. Despite the large number of studies and various recommendations, a reliable and practical model for the use of the structural designers is not yet available. Hence, usually the design practice ignores the contribution of the masonry in undertaking the seismic force, which leads to the oversizing the structural elements.

Reviewing the main references about the subject, it can be observed that the authors have tried to determine the geometrical and mechanical characteristics of the infill. Various formulations for the width of the diagonal strut and for the strength of the panel have been developed. Some of the recommendations have been adopted in the national codes, without yet a unitary approach of the issue. 
The present paper aim is to investigate the problems of the infill characteristics and seismic behavior by representative case studies. Analyzing the equations for the width of the diagonal strut on three different frames, it has been concluded that the Paulay and Priestley formulation is the most suitable choice, due to its reliability and simplicity. Although, as a result of the parametrical study issued according to three national codes recommendations, the paper suggest that for frames with the opening between $4 m$ and $6 m$ and with similar characteristics of the materials, the value of the infill strength can be considered to be $135 \mathrm{kN}$. These suggestions could constitute a practical model for the use of the structural designers.

In order to analyze the influence of the infills on the overall seismic behavior and to apply the above recommendations, three different structural systems have been studied: bare frame structures, without masonry; concrete frames with infill panels separated through joints from the structure; frames in contact with the masonry, which co-operate within carrying the lateral loads. A number of 12 push-over analyses were carried out, having as results the capacity curves for frames with different number of stories in each structural system. The results are relevant in proving the positive influence of the infills: the increase of the load-carrying capacity of $138 \%$, the stiffness increase of $721 \%$, for the frames that interact with the masonry.

For further research directions, a more elaborate study based on finite element method (FEM) could be issued in order to compare the results with the present paper conclusions on the strut width and the infill strength. However, extensive analysis upon infilled frames with various characteristics could be taken in considerations in order to get more exact results on the behavior to the seismic action.

\section{REFERENCES}

[1] $\quad$ xxx Eurocode 8 - Design of structures for earthquake resistance. Belgia

[2] xxx CR6-2006 - Codul de proiectare pentru structuri din zidărie, Romania

[3] xxx FEMA 306 - Evaluation of Earthquake Damaged Concrete and Masonry Wall Buildings, Federal Emergency Management Agency, USA

[4] xxx NZSEE - Assessment and Improvement of the Structural Performance of Buildings in Earthquakes, Recommendation of a NZSEE Study Group on Earthquake Risk Buildings, New Zeeland

[5] S.V. Polyakov, On the interaction between masonry filler walls and enclosing frame when loading in the plane of the wall, Translation in earthquake engineering, Earthquake Engineering Research Institute, San Francisco (1960)

[6] M. Holmes, Steel frames with brickwork and concrete infilling, Proceedings of the Institution of Civil Engineers 19, 1961.

[7] B. Stafford Smith, Behaviour of Square Infilled Frames, Proceedings of the American Society of Civil Engineers, Journal of Structural Division, 92, no STI, 1966381-403.

[8] B. Stafford Smith, C. Carter, A method of analysis for infill frames, Proc. Inst. Civil Engrs, 1969.

[9] R.J. Mainstone, On the Stiffness and strength of infilled frames, Proc. Supplement, Trans. of Instn. Of Civil Engrs, State Univ. of New York, 1974.

[10] M.R.A. Kadir, The structural behaviour of masonry infill panels in framed Structures, PhD Thesis, University of Edinburgh, 1974.

[11] T.C. Liaw, K.H. Kwan, Nonlinear behavior of non-integral infilled frames, Comput. Struct. 18, 1984, 551-560.

[12] L.D, Decanini, G.E. Fantin, Modelos simplificados de la mamposteria incluida en porticos. Caracteristicas de rigidezy resistencia lateral en estado limite, Jornadas Argentinas de Ingenieria Estructural, Buenos Aires, Argentina, Vol.2, 1986, pp.817-836.

[13] J.L. Dawe, C.K. Seah, Analysis of concrete masonry infilled steel frames subjected to in-plane loads, Proceeding of the 5th Canadian Masonry Symposium, Vancouver, 1989, p. 329-40

[14] A.W. Hendry, Structural masonry, London: MacMillan Education Ltd., 1990.

[15] T. Paulay, M.J.N. Priestley, Seismic Design of Reinforced Concrete and Masonry Buildings, John Wiley \& Sons, New York, 1992

[16] S.H. Bertoldi, L.D. Decanini, C. Gavarini, Telai tamponati soggetti ad azioni sismiche, un modello semplificato: confronto sperimentale e numeric, Atti del 6 Convegno Nazionale ANIDIS, vol. 2, Perugia, 13-15 Ottobre 1993 [in Italian], p. 815-24.

[17] A.J. Durrani, Y.H. Luo, Seismic Retrofit of Flat-slab Buildings with Masonry Infills, NCEER workshop on seismic response in Masonry Infills, 1994.

[18] L. Cavaleri., M. Papia, A new dynamic identification technique: application to the evaluation of the equivalent strut for infilled frames, Engineering Structures 25, 2003, 889-901.

[19] Xxx P 100-1/2006 - Cod de proiectare seismică - Prevederi de proiectare pentru clădiri, Romania.

[20] V.G. Pereira, R.C. Barros, M.T. César, A Parametric Study of a R/C Frame Based on Pushover Analysis, Proceedings of the 3rd International Conference on Integrity, Reliability and Failure, Porto/Portugal, 2009 